\title{
(70) Petrovi ke kulatinám přeje Mojmír
}

Petr Karlík se narodil 11. února 1951 v Uherském Hradišti. V roce 1969 začal své studium oboru čeština a němčina na Filozofické fakultě dnešní Masarykovy univerzity. První akademický titul získal v roce 1974 obhajobou diplomové práce Závislé otázky zjištovací. Od začátku akademické kariéry se zaměřil na syntax češtiny, ve své disertační práci z roku 1980 Vývoj funkcí kondicionálu $v$ češtině se věnoval české syntaxi z pohledu diachronního, poté však především z pohledu synchronního. Během studia na Ústavu českého jazyka potkal Petr Karlík mnoho významných bohemistů, z nichž se následně stali jeho kolegové a v některých př́padech spoluautoři jeho dalších publikací; mezi nejvýznamnější jména zcela jistě patří Radoslav Večerka, Roman Mrázek nebo Miroslav Grepl. Minimálně stejně významným faktorem, jakým byla česká lingvistická scéna (nejen) v Brně, bylo pro Petra Karlíka získání Humboldtova stipendia, díky němuž v letech 1982-1983 pobýval na Hamburské univerzitě. V roce 1984 a v letech 1987-1988 pak pokračoval v akademických stážích na Řezenské univerzitě, což bylo velmi štastné načasování, protože na řezenské katedře lingvistiky působili někteří z tehdejších a budoucích špiček německé i světové formální lingvistiky, např́klad Gisbert Fanselow, Peter Staudacher nebo Jindřich Toman; ti všichni měli na Petra Karlíka velký vliv. V roce 1985 se pak dočkal na domácí univerzitě jmenování docentem českého jazyka. O deset let později pak svou docenturu potvrdil obhajobou habilitační práce Studie o českém souvětí. V roce 1998 byl jmenován profesorem českého jazyka. V té době se kolem něj také začala utvářet skupina žáků, z nichž někteří následně formují to, co bychom mohli nazvat hnutím brněnské formální lingvistiky.

Petr Karlík spojil svou lingvistickou práci především s Masarykovou univerzitou, ale byl spíše rozkročený mezi evropskou lingvistickou scénou a domácí bohemistikou; v roce 1995 pracoval jako hostující profesor v Řezně a často ho bylo možné slyšet na dalších lingvistických katedrách po celé Evropě, at už to byla Postupim, Vídeň, Lublaň, Udine nebo Neapol. Ze svých akademických stáží v zahraničí si odvezl pochopení toho, že lingvistika znamená především hledání pravidel, která, i když nejsou vidět přímo v datech, vysvětlují zdánlivý chaos jazykových dat (jak to trefně vystihuje Сномsкy 2014: „[...] the whole goal of science is to replace complex visibles by simple invisibles. That is science. If you are not doing that [...] it is flower collection."). Petr Karlík si tuto zásadu vzal k srdci a postupně ji začal 
rozvíjet ve svých vlastních pracích a prosazovat ji také v rámci české lingvistiky. Zvláště druhý úkol nebyl úplně lehký, protože převládající paradigma bohemistiky nebylo rozhodně formální. Myslím, že nelze přesně kvantifikovat podíl Petra Karlíka na akceptaci formální lingvistiky v současné bohemistice, ale je jisté, že v Brně díky jeho vlivu vzniklo několik lingvistických skupin, které drží krok se současnou světovou lingvistikou, at už v oblasti fonologie a morfo-syntaxe nebo formální a experimentální sémantiky. Jsem si jistý, že bez Petra Karlíka by k tomuto (pro českou lingvistiku myslím velmi dobrému) zvratu nedošlo. Článků, knih, přednášek, ve kterých Petr Karlík realizuje tuto Chomského koncepci lingvistiky, existuje opravdu mnoho, jen jejich soupis je mnohostránkový: jeden (pokrývající roky 2010-2020) najdeme za tímto medailonkem, druhý (věnující se předchozím letům) se nachází v článku V. BLAžKA (2011). Není mou ambicí zde vyjmenovávat ani ty nejdůležitější publikační počiny, kterými Petr Karlík přispěl k české i světové lingvistice, nicméně jednu knihu opravdu přehlédnout nejde, a tou je Nový encyklopedický slovník češtiny (KARLí́ - NeKula - Pleskalová et al. 2016, dále NESČ), ve kterém Petr Karlík vystupoval nejen jako jeden ze tř́ hlavních editorů (společně s Markem Nekulou a Janou Pleskalovou), ale také jako autor. NESČ je skutečně monumentální dílo: vyneseme-li si na osu $x$ roky $1990-2020$ a na osu $y$ počet publikací Petra Karlíka, získáme korelační diagram, v němž je median 4, zatímco mean činí 10.7 publikací za rok; rozdíl mezi meanem a mediánem prostě plyne z outlieru NESČ, do kterého Petr Karlík přispěl neuveřitelnými 200 hesly pokrývajícími téměř celou oblast formální syntaxe. $V$ těchto heslech se mu podařilo spojit své formálně-lingvistické myšlení se svou další silnou stránkou, což je schopnost jasně a srozumitelně popsat někdy i značně komplexní teorie. NESČ je nyní v české lingvistice používaný jako lingvistická encyklopedie, ze které vycházejí nejen pokročilí studenti, ale i všichni lingvisté, kteří potřebují rychlou, konzistentní a jasnou informaci o daném tématu. NESČ je jenom vrcholem pyramidy systematického snažení, které začalo už v letech 1998-2003, kdy Petr Karlík (spolu s dalšími kolegy z Ústavu českého jazyka FF MU) pořádal šlapanicko-brněnské konference Čeština - univerzália a specifika. Ǩada těchto konferencí vykrystalizovala do proto-NESČ, Encyklopedického slovníku češtiny (2002, stejní hlavní editoři jako NESČ). NESČ je tedy vyústěním systematické, dlouhodobé a úspěšné snahy Petra Karlíka po vystavění solidních základů (nejen formální) jazykovědy v České republice. Toto úsilí bylo podpořeno řadou grantových projektů, které umožnily Petru Karlíkovi shromáždit kolem sebe řadu významných a vlivných lingvistů pracujících v duchu Denise Diderota na tom, aby pro českou lingvistiku napsali obdobu Ottova slovníku naučného.

Petr Karlík je v české lingvistice zkrátka vlivný v tom nejlepším slova smyslu. Jiným zřejmým dokladem je sborník k jeho sedmdesátým narozeninám, který najdeme na prestižním a velmi vlivném lingvistickém serveru lingbuzz (https://lingbuzz. com/t/karlik/). V tomto sborníku nalezneme jak př́mé žáky Petra Karlíka (Pavel Caha, Markéta Ziková a autor tohoto medailonu), tak lingvisty světového renomé, 
které Petr Karlík at už přímo, nebo nepřímo ovlivnil (Petr Biskup, Joe Emonds, Petr Kosta, Ivona Kučerová, Michal Starke, Ludmila Veselovská). K tomuto výčtu patří řada dalších bývalých i současných doktorandů, jmenujme alespoň Lindu Doleží, Lucii Janků, Ruth Konvalinkovou, Pavla Koska, Jaroslava Kyncla, Petru Macurovou, Annu-Marii Perissutti, Lucii Stehlíkovou, Rolanda Antona Wagnera... Tento výčet by mohl pokračovat velmi dlouho (stejně jako u publikací Petra Karlíka), čímž bych bohužel vyčerpal prostor přidělený tomuto medailonku. Stále rostoucí řada žáků je podobně jako úroveň a množství citací NESČ v nejrůznějších publikacích rovněž dokladem dobrého vlivu Petra Karlíka na českou lingvistiku.

Jsem hrdý na to, že jsem jedním z žáků Petra Karlíka. Čím mě, stejně jako spoustu jiných, inspiroval, byla autenticita, se kterou lingvistiku prožíval jako svého druhu mentální dobrodružství, které je při dodržení všech formálních pravidel především úžasně zábavnou snahou po nalezení takových skrytých mechanismů jazyka, které hýbají zdánlivým chaosem dat na povrchu. Petře, přeju Ti vše nejlepší k sedmdesátým narozeninám. A moc se těším, až spolu u Pegasa na zahrádce probereme, na čem právě pracuješ.

\section{LITERATURA}

BLAžEK, Václav. 2011. Petr Karlík sexagenarius. Linguistica Brunensia 59 (1-2), 253-262.

Сномsкy, Noam. 2014. Simple invisibles. In: Veselovské, Ludmila - Janebová, Markéta, eds. Complex Visibles Out There. Olomouc: Palacký University, 17-27.

Karlík, Petr - NekUla, Marek - Pleskalová, Jana et al. 2016. Nový encyklopedický slovník češtiny. Praha: Nakladatelství Lidové noviny.

\section{Mojmír Dočekal}

Department of Linguistics and Baltic Languages

Faculty of Arts, Masaryk University

Arna Nováka 1, 602 oo Brno

Czech Republic

docekal@phil.muni.cz 